\section{Probable Qualitative Inheritance of Full Red Skin Color in Peach}

\author{
T.G. Beckman ${ }^{1}$ \\ U.S. Department of Agriculture, Agricultural Research Service, Southeastern \\ Fruit and Tree Nut Research Laboratory, Byron, GA 31008
}

\author{
W.B. Sherman ${ }^{2}$ \\ Horticultural Science Department, University of Florida, Gainesville, FL 32611
}

Additional index words. Prunus persica, breeding

\begin{abstract}
Recently observed hybrid populations of peach [Prunus persica (L.) Batsch] provide evidence for the presence of a single gene controlling full red skin color. The fruit of seedling populations of 'UFQueen' $x$ 'Springbaby', 'UFQueen' $x$ 'Springprince', FL93-12C x 'Springprince', FL92-22C x BY79P1945, and AP98-18 o.p. were rated for percent red skin color at full maturity. At this stage of development, "full red" phenotypes display red color over the entire surface of the fruit, including the stem cavity and portions of the fruit shaded by leaves or stems. Both crosses with 'UFQueen' yielded populations displaying a 1:1 segregation ration for partial red : full red. All other crosses produced populations that did not deviate significantly from a 3:1 segregation ratio. These data are consistent with the hypothesis that the "full red" phenotype is a single gene recessive trait. We propose the gene symbols of $f r$ and $F r$ for the recessive full red and dominant partial red (wild-type) alleles, respectively.
\end{abstract}

Red skin color is a desirable trait contributing to the attractiveness of a peach. Hence, high levels of red blush are sought in most breeding programs developing cultivars for the fresh market (Scorza and Sherman, 1996). Several reports have been published on the expression and inheritance of red skin color (Blake, 1932, 1940; Hansche, 1986; Weinberger, 1944; ), all of which concluded that it was under the control of multiple genes. We present evidence for the presence of qualitative gene action controlling anthocyanin production in the epidermis of peach fruit.

Fruits of seedling populations of 'UFQueen' (Sherman and Lyrene, 1999) x 'Spring Baby' (Okie, 1998), 'UFQueen' x 'Springprince' (Frecon and Johnson, 1999), FL93-12C x 'Springprince', FL92-22C x BY79P1945, FL92-22C x (FL95-1NW/FL94-5NW pollen bulk), and AP98-18 o.p. were evaluated during either the 2000 or 2001 fruiting seasons. At the full ripe stage, i.e., when soft for melting types and yielding (but still resilient) for non-melting types, fruits were rated to the nearest $10 \%$ red skin color. At this stage of development, full red phenotypes have developed red color over the entire surface of the fruit, including the stem cavity and portions of the fruit shaded by leaves or stem.

The phenotype data observed for the FL9222C x (FL95-1NW/FL94-5NW pollen bulk) progeny are typical of those expected for a trait demonstrating additive gene action. The seed parent, FL92-22C, typically produces fruits with $30 \%$ red skin color at maturity while the pollen parents, a mixture of FL95-1NW and FL94-5NW, both typically display $\approx 90 \%$ red.

Received for publication 4 Aug. 2002. Accepted for publication 3 Mar. 2003.

'Research Horticulturist.

${ }^{2}$ Professor. evaluated at Attapulgus, Ga. (2000 or 2001).

${ }^{\mathrm{z}}$ Nectarine phenotype.

yeach phenotype. heterogeneity.

"FL93-12C = 'Aztec Gold' $\mathrm{x}$ 'Oro A'.

'FL92-22C = 'Aztec Gold' $x$ 'Oro A'.

"BY79P1945 = VPI117 o.p.

'AP98-18 = FL92-23C (= 'Conserva' x 'Oro A') x 'Spring Baby'.

'FL95-1NW = FL88-18W (= 'Flordaglo' o.p. $)$ x 'Suncoast'.

${ }^{\mathrm{r}} \mathrm{FL} 94-5 \mathrm{NW}=\mathrm{FL84}-18 \mathrm{C}$ (= 'Oro A' X 'Sunmist') o.p. significantly from a 3:1 (partial red : full red) phenotypic segregation ratio. The phenotypic distributions for the partial red progeny from 'UFQueen' x 'Spring Baby' (Fig. 1B) and FL92-22C x BY79P1945 (Fig. 1C) indicate that quantitative segregation for percent skin color is also occurring in these populations. These data also appear to indicate that the homozygous full-red genotype may be masking the expression of the quantitative red genotypes similar to the recessive epistasis observed in conjunction with the white flower (W) locus of peach (Lammerts, 1945).

These data are consistent with the hypothesis that the "full red" phenotype is a single gene recessive trait. We propose that the recessive allele controlling full red skin development is present in the homozygous state in 'UFQueen' and that 'Spring Baby', 'Springprince', FL93-12C, FL92-22C, BY79P1945, and AP98-18 are heterozygous. Selections FL95-1NW and FL94-5NW are evidently both homozygous for the dominant allele. We propose the gene symbols of $f r$ and $F r$ for the recessive full red and dominant partial red (wild-type) alleles, respectively.

This trait should prove useful in breeding fresh market peach and nectarine cultivars, as red blush development in the full red phenotypes is profoundly accelerated providing very high percent red blush at the "shipping ripe" stage, i.e., as ground color starts to change from green to yellow. Full red color development is achieved in many seedlings before any shift in ground color is observed.

\section{Literature Cited}

Blake, M.A. 1932. The J.H. Hale as a parent in peach crosses. Proc. Amer. Soc. Hort. Sci. 29: 131-136.

Blake, M.A. 1940. Some results of crosses of early ripening varieties of peaches. Proc. Amer. Soc. Hort. Sci. 37:232-241.

Frecon, J.L. and C.E. Johnson. 1999. Peach. In: W.R. Okie (ed.). Register of new fruit and nut varieties. List 39. HortScience 34:192-194.

Hansche,P.E. 1986. Heritability of fruit quality traits in peach and nectarine breeding stocks dwarfed

Table 1. Distribution of partial red skin color phenotypes and full red skin color phenotypes from crosses

\begin{tabular}{|c|c|c|c|c|c|c|}
\hline Cross & $\begin{array}{l}\text { Seedlings } \\
\text { rated }\end{array}$ & $\begin{array}{c}\text { Partial } \\
\text { red }\end{array}$ & $\begin{array}{c}\text { Full } \\
\text { red }\end{array}$ & $\begin{array}{l}\text { Test } \\
\text { ratio }\end{array}$ & $\chi^{2}$ & $P$ \\
\hline UFQueen $^{z}$ x Spring Baby ${ }^{y}$ & 83 & 42 & 41 & $1: 1$ & 0.012 & 0.91 \\
\hline UFQueen $^{\mathrm{z}} \mathrm{x}$ Springprince ${ }^{\mathrm{y}}$ & 14 & 7 & 7 & $1: 1$ & 0.000 & 1.00 \\
\hline Pooled $^{\mathrm{x}}$ & 97 & 49 & 48 & $1: 1$ & 0.010 & 0.92 \\
\hline FL93-12C ${ }^{y, w}$ x Springprince ${ }^{y}$ & 19 & 15 & 4 & $3: 1$ & 0.158 & 0.69 \\
\hline FL92-22C ${ }^{y v} \times$ BY79P1945 & 29 & 21 & 8 & $3: 1$ & 0.103 & 0.75 \\
\hline AP98-18 ${ }^{\mathrm{y}, \mathrm{t}}$ o.p. & 35 & 26 & 9 & $3: 1$ & 0.010 & 0.92 \\
\hline Pooled $^{\mathrm{x}}$ & 83 & 62 & 21 & $3: 1$ & 0.004 & 0.95 \\
\hline FL92-22C ${ }^{\mathrm{y}, \mathrm{v}} \times\left(\right.$ FL95-1NW ${ }^{\mathrm{z}, \mathrm{s}} /$ FL94-5NW $\left.{ }^{\mathrm{z}, \mathrm{r}}\right)$ & 44 & 44 & 0 & $1: 0$ & 0.000 & 1.00 \\
\hline
\end{tabular}

${ }^{x}$ Pooled samples were generated for the 1:1 and 3:1 segregation classes, respectively, after testing for 


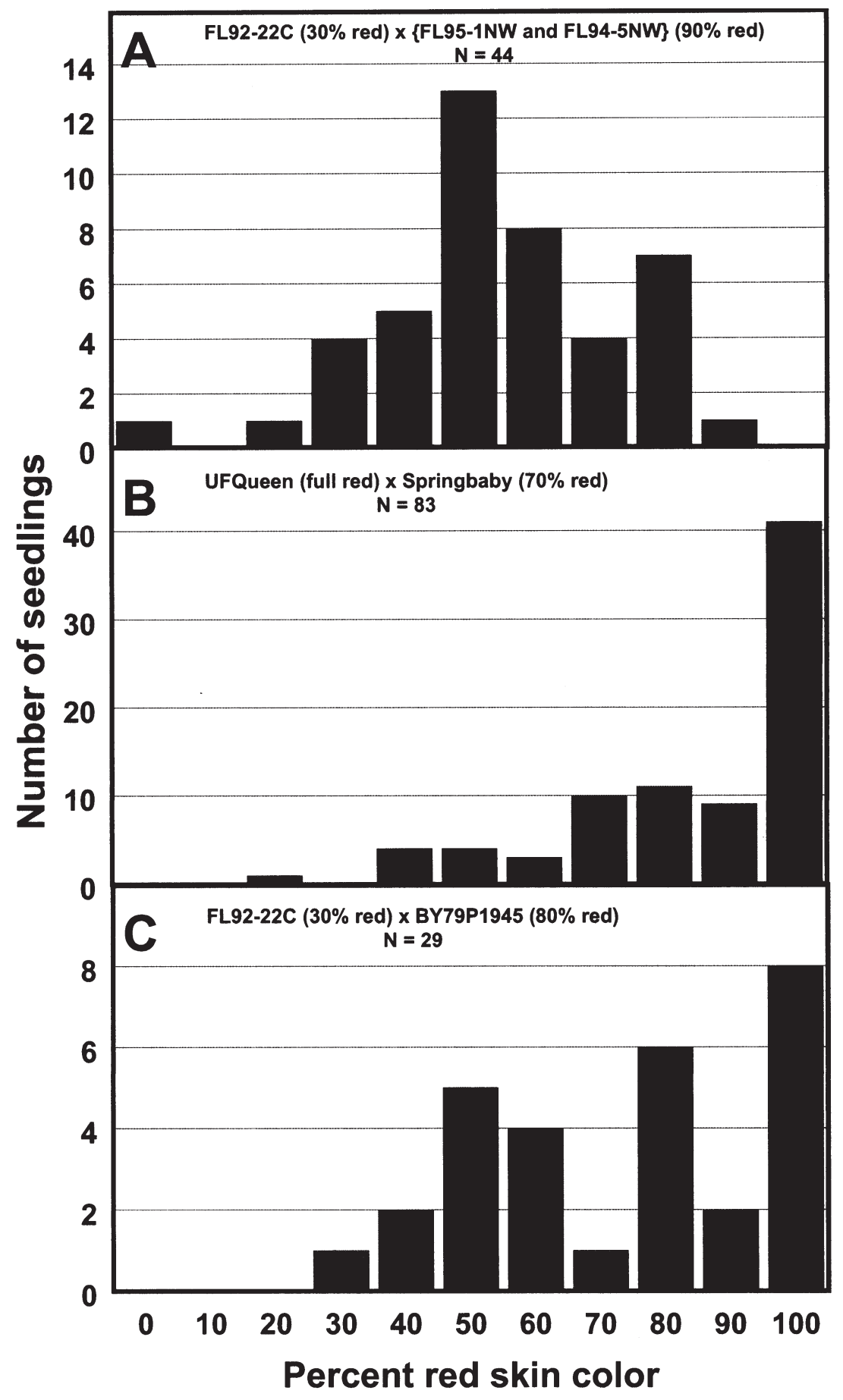

Fig. 1. Distribution of red skin color in seedlings of three peach crosses. by the $d w$ gene. HortScience 21:1193-1195. Lammerts, W.E. 1945. The breeding of ornamental edible peaches for mild climates, 1: Inheritance of tree and flower characters. Amer. J. Bot. 32: 53-61.

Okie, W.R. 1998. Handbook of peach and nectarine varieties. U.S. Dept. Agr. Hdbk. No. 714.

Scorza, R. and W.B. Sherman. 1996. Peaches, p. 325-40. In: J. Janick and J.N. Moore (eds.). Fruit breeding, vol. 1. Tree and tropical fruits. Wiley, New York.

Sherman, W.B. and P.M. Lyrene. 1999. 'UFQueen' nectarine. Fruit Var. J. 53:126-127.

Weinberger, J.H. 1944. Characteristics of the progeny of certain peach varieties. Proc. Amer. Soc. Hort. Sci. 45:233-238. 